\title{
Governance: Mature Paradigm or Chicken Soup for European Public Management?
}

Sørensen and Torfing assert that "governance" has become a highly influential paradigm, able to influence the conduct of governing and thus contribute to improving our economies and societies. In responding, we take issue with this pivotal claim, arguing that governance is rather a parochial and decaying paradigm, which failed to improve the way societies and economies were governed.

Sørensen and Torfing rightly observe that governance is a slippery notion. As a portmanteau concept, it is hard to object to. For good or ill, the current author routinely uses it: for example in discussing the intrinsically coercive nature of governing (Davies, 2012), disclosing "collaborative" mechanisms by which the dispossessions of austerity are normalised (Davies and Blanco, 2017), or deexceptionalising Russia by showing how the regime selectively networks with civil society actors in certain policy arenas (Davies, et al 2016). The issue at stake, then, is "governance" in the narrower sense of the paradigm described by Sørensen and Torfing.

Sørensen and Torfing helpfully capture the essence of governance in this paradigmatic sense. They begin with its origins in the demise of the classical institutionalist preoccupation with the governmental and state apparatus. In contrast, governance focuses on the analysis of "complex processes", through which collective goals are formulated and delivered by a wide range of public and private actors who interact to "define problems, set goals, design solutions and implement them". They interpret governance, so defined, as a "complex, decentered, fluid and 
potentially chaotic process". Sørensen and Torfing further claim, importantly, that governance "expands the number of relevant actors, arenas and levels" constituting the terrain of analysis.

We see this (also nebulous) formulation as problematic for three reasons, all of which involve strategic elisions characteristic of the paradigm. First, it neglects a vast body of historic and contemporary social theory about state, market and civil society relations that could be employed to develop more resonant and encompassing perspectives on the spectrum of $21^{\text {st }}$ century governing arrangements (e.g. Gramsci, 1971; Stone, 1989). Second, and relatedly, the anchoring in doctrines that privilege social complexity make it inadequate as a theory of governing. Third, and by extension, the paradigmatic conception of governance seems detached from swathes of political reality that point more towards obsolescence than maturity.

It is striking, first of all, that Sørensen and Torfing dismiss debates about whether government is giving way to governance as "unfruitful". Yet, a recurring premise within the paradigm and their own work is that transformations are indeed taking place. And, they appear to welcome them. Governance is credited with disclosing "new ways of governing, new institutional arenas and new types of actors". Elsewhere, Torfing and Sørensen point to a "notable surge in pluricentric types of governance throughout Western Europe" (2014: 332). They claim, "governance networks are ubiquitous and seem to be proliferating to an astonishing extent" (2014: 335), especially in North-Western Europe.

We see this approach as problematic for two reasons. First, as Davies (2011a) argued in this journal, even a cursory engagement with early to mid $20^{\text {th }}$ 
century literatures suggests that interactive, collaborative and networked forms of governing emerged more or less as soon as civil society took to the historical stage, and throughout modernity. Older literatures reveal preoccupations in the age of "government" uncannily like those of today's governance theorists (as discussed in Davies, 2011a). There are myriad examples that do not fit the paradigmatic caricature of the "Westminster Model", typically employed by governance theorists to conjure up their "constituent other". If modern governing histories are replete with hierarchies, markets and networks, as they surely are, the claim that networks are "proliferating" or "surging" requires something more than repeated assertion. Where is this occurring? Where is it not? How do we know? Who is counting? Unfortunately, claims announcing deep quantitative and qualitative changes are recycled through paradigmatic governance literatures as an article of faith. Opening this issue to question immediately makes the empirical (and ideological) foundations of the whole paradigm look shaky.

Relatedly, the paradigmatic approach is selective in the bodies of theory it employs. As noted above, Sørensen and Torfing claim that "governance research expands the number of relevant actors, arenas and levels". The constituent other in this formulation is the much-maligned field of traditional public administration and its alleged preoccupation with bureaucracy. Even on this narrow ground, it does not stand much scrutiny (Lynn, 2001). On a broader intellectual terrain, it falls down entirely.

For example, Antonio Gramsci spent his lengthy incarceration under Mussolini excavating relations between state and civil society in the West, through his theories of hegemony and the integral state (Gramsci, 1971). To apply Sørensen 
and Torfing's criteria, in the Prison Notebooks Gramsci enormously expanded "the number of relevant actors, arenas and levels" (notably his famous polemic against Benedetto Croce), as well as analysing "regulatory frameworks" through which government interacts with other actors. Gramsci did this several decades before the "governance" paradigm announced itself. Moreover, he has been influential in at least one strand of critical governance studies (e.g. Jessop, 1997; Davies, 2011b; 2012). As a one-time thinker on Gramsci, Torfing (1998) himself contributed to this strand.

Our first substantive point, then, is that in its paradigmatic form, governance relies on unsubstantiated claims about social change, traduces traditional public administration and conceals resonant critical traditions that long ago developed relational accounts of governing through networks and could never plausibly be accused of ignoring non-state actors. It was conjured from a Euro-centric, particularistic and partial reading of social change, drawing a veil of discretion over other potentially more powerful processes and tendencies, with much greater geographical and historical reach. Governance has created a strong epistemic community based on a deeply problematic body of theory.

Second, there is a pronounced bias in the paradigmatic governance literatures to make assertions about "complexity" that require further scrutiny. In Sørensen and Torfing's paper, a good example is the rendering of social ills as "complex", "wicked and unruly problems". This discourse originates in the attempt by leading politicians in the 1990s and 2000s (such as Tony Blair, Bill Clinton and Gerhard Schröder) to infuse social democratic practices with capitalist realism drawing on ideas from Giddens' (1998) "The Third Way". To declare a "problem" 
"wicked and unruly", in the manner of "Third Way" ideology, arguably absolves economic and political elites of causal responsibility and recapitulates systemic pathologies as a-causal puzzles to be managed through social partnerships (see Fairclough, 2000 for an entertainingly devastating critique of Blairite language). It is not difficult to see how pre-defining "problems" as "complex", "wicked and unruly" imposes a form of de-politicized agenda control. Jessop (2007: 244), for example, cautioned that we should appreciate the "dialectic between the complexity of the real world and the manner in which the real world comes to be interpreted as complex". An adequate theory of governance would heed this advice by adopting at least some scepticism towards ideologies of complexity spewed out by $21^{\text {st }}$ century elites, which tend to be absorbed into the governance paradigm, as articles of faith.

The point is not to deny that many social phenomena are complex. It is rather that an appropriate theory of governance should problematize complexity. Are phenomena necessarily as complicated as we are encouraged to believe (e.g. Sassen, 2014)? Which political actors mobilise discourses of complexity for what reasons. Governance theory could also pay more attention to the ways that governing elites and theorists alike avow things to be simple when it suits them, amplifying or reducing complexity to exercise agenda control. In other words, an adequate governance theory would problematise the relationships between complexity and simplicity. To employ Torfing's earlier Gramscian analysis (1998: 46), the a priori assertion of complexity in governance theory "tends to marginalize and obscure the role of politics with regard to the structuring of capitalist social relations".

My third point is that as a consequence of these elisions, the vocabularies of governance tend to obscure injustices perpetrated, in part, by actors who 
themselves employ paradigmatic discourses. For example, as Clarke and Butcher (2009: 590) put it in a study of business school governance, governance discourses perpetrate "an illusion of participation that obscures institutionalized power relationships". Alonso (2001: 284) saw that the language of "networks" creates a "fog of ignorance" obscuring bullying and domination by the very managers circulating discourses of governance.

It is far from unusual to see governance employed in ways that, at times, make the paradigmatic discourse seem detached from reality. Nowhere is the paradigm employed more misleadingly than in relation to the political and economic dispossessions of austerity. Sørensen and Torfing (2014) call for research to address the lack of comparative and cross-national studies into network governance. Two of our recent studies try to address this lacuna by looking at what happens to governing processes in cities afflicted by austerity (e.g. Davies and Blanco, 2017). They pose fundamental questions to the governance paradigm. While inclusive governance arrangements might conceivably thrive in conditions of relative abundance, or when a municipality takes an antagonistic stance towards austerity and seeks to work with social movements (as in Barcelona), delivering austerity appears toxic to "governance" as a mechanism to "improve" the way societies and economies are governed.

In Athens, for example, the state attempted after the first EU austerity memorandum, to roll out a wave of participatory governance reforms as a vehicle for bringing citizens into semi-formal governing processes, including "deliberation committees" (Chorianopoulos and Tselepi, 2017). For reasons linked to the development of the Greek state after the restoration of democracy in 1974, it had 
not been able or willing to do so before, despite encouragement from the EU. At the same time, the municipality has been coalition building with the philanthropic wings of global corporations such as Bloomberg, Onassis and Rockefeller, now influential actors in governing the city. These developments are iteratively producing an elitepluralist urban regime with a policy agenda closed to influence from non-privileged layers of civil society.

Meanwhile, in attempting to cope with the human crisis caused by austerity governance, activists have established myriad informal solidarity networks to help people survive. Many refuse all engagement with the local state and its participatory apparatus. For a community activist commenting on this rejectionist stance, adopted since the July 2015 referendum, it “wasn't about the Euro or Grexit. It was about austerity. You can't stand out as the main proponent of the 'yes' vote, as the mayor did, knowing that what we stand for is negated by the 'yes' vote". For another respondent, "there's this growing realization that we're on our own, under no protective umbrella of any formal authority or institution. Not only that, but that we're actually against them". Ironically, these organisations could not participate even if they wanted to, because the City limits potential civil society partners to formal legal entities, sanitizing and simplifying "governance" by keeping contentious politics out of it.

In Athens, despite the creation of token deliberation committees and other similar mechanisms, austerity appears to have destroyed much of the social basis for pluricentric networks, rendering paradigmatic "governance" marginal, if not redundant, in that city. The state apparatus has driven austerity in a hierarchical, authoritarian fashion, with the collusion of global, European, national and local 
elites. Austerity has caused grievous suffering, destroyed networks and further empowered the powerful, notably agents of the non-profit industrial complex like Bloomberg. Unsurprisingly, civil society actors operating at the boundaries of resistance and assistance wanted no part in it.

Studying practical struggles in Athens at a time of deep retrenchment only highlighted the limited and diminishing potential for forging interactive or collaborative governance arrangements capable of blurring or resolving disagreements in society. Other case studies - notably Baltimore, Dublin, Leicester and Montreal - also suggested that austerity is an important factor in undermining the foundations of pluricentric network governance and of centralizing power in a variety of disciplinary neoliberal state apparatuses (Davies, 2017).

Hence, vast spaces of real-world governing appear to undermine the prospects for "governance" as a constructive dialogic process. Of course, these processes can rendered as "governance" in the portmanteau sense of the term discussed earlier, or through the lens of critical governance theories such as those inspired by Gramsci. The key issue is that as a paradigmatic approach, "governance" cannot recognize either the dramatic retrenchment of pluricentric and network practices in its European heartlands, or account theoretically for this retreat. Nor, unlike Gramscian theory, does the paradigmatic approach possess vocabularies and conceptual tools needed to grasp the constitution of (old and new) authoritarianism(s).

One possible explanation for these lacunae lies in the origins of the paradigm in the years of post-Soviet Western hubris. The paradigm emerged at a time when eminent Western theorists expected things to pan out very differently. Preparing 
the ground for his "Third Way", Giddens (1994) announced an age of post-scarcity, in which old class-based struggles for subsistence could be surmounted for open, affective and trust-based social relations self-organised through networks. With dramatic political and economic reversals afflicting millions in Europe alone, the period since 2008 has been a painful correction to delusions of this nature.

Governance, arguably, remains trapped in a normative bubble.

Techniques of paradigm closure through which governance insulates itself from criticisms like this, are also evident in Sørensen and Torfing's essay. They acknowledge three prominent modes of criticism levelled at governance scholars: that "governance is a marginal phenomenon; that even if it is a significant phenomenon, it is by no means new; and that if it is new, it has dangerous implications". This is an excellent summary of major lines of critique. It is regrettable that Sørensen and Torfing choose not to engage them and instead dismiss them as "unfruitful". We suggest that governance theory could be much improved if it took them seriously.

All this leads us to suggest a fourth mode of criticism: that as a paradigm, "governance" is increasingly disconnected from the world around it. While Sørensen and Torfing comment that early "harsh" criticisms put governance on the "defensive", the attainment of "orthodoxy" (Marsh, 2011) has allowed movers of the paradigm to ignore interlocutors, while normalising a plethora of deeply problematic assumptions. At issue is not the existence of paradigms as such, but the impoverishment of a theory of governance that remains stuck with normative and analytical baggage imported in the radically different conjuncture of the 1990s. 
History tells us that paradigms have a life cycle. Eventually, they fade or are driven from the historical stage. Some are more durable than others, for a host of good and bad reasons. As Beck (1992: 46-7) pointed out in seeking to bury first modernity, paradigms often outlive the historical conditions that gave rise to them, and survive only as "zombie categories". The concluding argument is that even if it had been founded on a sound theoretical and empirical basis 25 years ago, paradigmatic governance theory is now well past maturity and entering the phase of decay. This is to say that although it remains influential, especially in de-politicized public management discourses, it cannot assist us in understanding or changing the world for the better.

Perhaps the most striking indicator of decay is that key architects of the paradigm cited by Sørensen and Torfing, have either distanced themselves or repudiated it (e.g. Rhodes, 2011; Stoker, 2011; Grote, 2012). A new paradigm is required that is capable of grasping governance in a phase of socioeconomic and political crisis, spiraling inequality, authoritarian statism and "brutal simplicities" (Sassen, 2014: 4) that go hand-in-hand with all the complexity. To develop such a theory, we would be wise to draw on traditions of critical policy and critical governance studies, to which Sørensen and Torfing made vital contributions in the past.

\section{Acknowledgements}

The research discussed in this paper was funded from two sources. The Spanish Government's Ministry of Economy and Competitiveness funded TRANSGOB under its National Development Plan (Ref: CSO2012-32817). See https://transgob.net. The 
UK Economic and Social Research Council funded Collaborative Governance under Austerity: An Eight-case Comparative Study (Ref: ES/L012898/1), led by Professor Jonathan Davies. See http://cura.our.dmu.ac.uk/category/austerity-governance/.

\section{References}

Alonso, L.E. 2001. New myths and old practices: postmodern management discourse and the decline of Fordist industrial relations'. Transfer: European Review of Labour and Research, 7(2): 268-288.

Beck, U. (1992) Risk society: Towards a New Modernity, London: Sage.

Chorianopoulos, I. and Tselepi, N. 2017. Austerity Urbanism: Rescaling and

Collaborative Governance Policies in Athens. European Urban and Regional Studies.

Published online before print $30^{\text {th }}$ September 2017.

https://doi.org/10.1177/0969776417733309.

Clarke, M., and Butcher, D. 2009. Political leadership, bureaucracies and business schools: a comfortable union'? Management Learning, 40(5): 587-607.

Davies J S, 2011a, The limits of Post-traditional Public Administration: Towards a Gramscian Perspective. Critical Policy Studies, 5(1) 47-62.

Davies J S. 2011b. Challenging Governance Theory: From Networks to Hegemony. Bristol: Policy Press. 
Davies J S. 2012. Network Governance Theory: A Gramscian Critique. Environment and Planning A, 44(11): 2687-2704.

Davies J S. 2017. Governing in and against Austerity: International Lessons from Eight Cities. ISBN: 978-1-85721-432-1.

Davies J S, and Blanco I. 2017. Austerity Urbanism: Patterns of Neoliberalisation and Resistance in Six Cities of Spain and the UK. Environment and Planning A. 49(7): 1517-1536.

Davies J S, Jørn Holm-Hansen, Vadim Kononenko \& Asbjørn Røiseland.

2016. Network Governance in Russia - an Analytical Framework, East European Politics, 32(2): 131-147.

Fairclough, N. 2000. New Labour, New Language. London: Routledge.

Giddens, A. 1994. Beyond Left and Right: The Future of Radical Politics, Cambridge: Polity Press.

Giddens, A. 1998. The Third Way. Cambridge: Polity Press.

Gramsci, A. 1971. Selections from Prison Notebooks, London: Lawrence \& Wishart. Translated by Quintin Hoare and Geoffrey Nowell-Smith. 
Grote J R. 2012. Horizontalism, Vertical Integration and Vertices in Governance Networks. Stato e Mercato, 94: 103-134.

Jessop, B. 1997. AA neo-Gramscian approach to the regulation of urban regimes: accumulation strategies, hegemonic projects and governance', in M. Lauria, ed, Reconstructing Urban Regime Theory: Regulating Urban Politics in Global Economy, London: Sage, pp. 51-73.

Lynn, L.E. 2001. The myth of the bureaucratic paradigm: what traditional public administration really stood for. Public Administration Review, 61 (2): 144-160.

Marsh D. 2011. The new orthodoxy: the differentiated polity model", Public Administration 89(1): 32-48

Rhodes R A W. 2011. Thinking on: a career in public administration, Public Administration 89(1): 96-212.

Sassen S. 2014. Expulsions: Brutality and Complexity in the Global Economy. Harvard: Harvard University Press

Stoker G. 2011. Was local governance such a good idea? A global comparative perspective" Public Administration, 89(1): 15-31 
Stone C N. 1989. Regime Politics: Governing Atlanta 1946-1988. Lawrence, KS:

University of Kansas Press.

Torfing J. 1998. Politics, Regulation and the Modern Welfare State. Basingstoke: Palgrave Macmillan.

Torfing J and Sorensen, E. 2014. The European debate on governance networks: Towards a new and viable paradigm? Policy and Society, 33(4): 329-344. 